\title{
Absorption and cutaneous deposition of yellow pigment in male and female broilers in response to different levels of xanthophylls from Tagetes erecta
}

\author{
MA Tepox-Pérez ${ }^{\mathrm{a}}$, B Fuente-Martínez ${ }^{\mathrm{b}^{*}}, \mathbf{X}$ Hernández-Velasco ${ }^{\mathrm{a}}$, \\ M Quiroz-Pesina ${ }^{\mathrm{c}}$, E Ávila-González ${ }^{\mathrm{b}}, \mathbf{G}$ Téllez $^{\mathrm{d}}$
}

\begin{abstract}
To determine the saturation point of absorption and cutaneous deposition of yellow xanthophylls (XA) in broilers, two hundred and sixteen Ross 308 chickens (108 males and 108 females) were sorted by sex and randomly assigned to 6 dietary treatments containing 6 replications of 6 birds each. Treatments consisted of increasing levels of xanthophylls from Aztec marigold flower (Tagetes erecta) $(65,92,119,146,173$, and $200 \mathrm{ppm})$. Weight gain, feed consumption, and feed conversion were measured weekly. Plasma pigment levels and skin yellowness in live birds were measured twice per week. Growth performance was analysed through ANOVA for a 6 X2 factorial arrangement, where the first factor was the XA adding at six levels, and the second factor was sex at two levels. Pigment plasma concentration and skin yellowness were fitted into a multiple linear regression model. Results indicated that the highest levels of plasma xanthophylls and skin yellowness were found after $28 \mathrm{~d}$ of feeding. Skin yellowness increased by $2.24 \mathrm{~b}^{*}$ for every $\mathrm{d}$ of xanthophylls consumption. In the females, skin yellowness was $1.35 \mathrm{~b}^{*}$ higher than in the males. Increasing dietary xanthophylls by $10 \mathrm{ppm}$ was reflected in $0.83 \mathrm{~b}^{*}$ of increase in skin yellowness.

Key words: Tagetes erecta, broiler chicken, plasma xanthophylls, yellow skin pigmentation.
\end{abstract}

RESUMEN. Para evaluar el punto de saturación en la absorción y depósito cutáneo de xantofilas amarillas (XA) en pollos de engorda, doscientos dieciséis pollos (108 machos y 108 hembras) Ross 308 fueron asignados aleatoriamente a 6 tratamientos, cada uno con seis réplicas con seis aves cada una. Los tratamientos consistieron en adicionar al alimento seis niveles diferentes de XA de flor de cempasúchil (Tagetes erecta) $(65,92,119,146,173$, y 200 ppm). La ganancia de peso, consumo de alimento y conversión alimenticia se midieron semanalmente. Los niveles de pigmento plasmático y amarillamiento cutáneo en aves vivas se midieron dos veces por semana. La ganancia de peso se analizó con ANOVA mediante un arreglo factorial 6×2 (primer factor los niveles de XA y el segundo factor el sexo). La concentración plasmática de pigmento y el amarillamiento en piel se analizaron mediante un modelo lineal de regresión múltiple. Los resultados indicaron que los mayores niveles de XA en plasma y piel se encontraron después de 28 días de alimentación. El amarillamiento en piel aumentó 2,24 b* por cada día de consumo de XA. En las hembras, el amarillamiento en piel fue $1,35 \mathrm{~b}^{*}$ mayor que en los machos. El aumento de $10 \mathrm{ppm}$ de XA en la dieta se reflejó en un incremento de $0,83 \mathrm{~b}^{*}$ de amarillamiento en piel.

Palabras clave: Tagetes erecta, pollos de engorde, xantofilas plasmáticas, amarillamiento cutáneo.

\section{INTRODUCTION}

Despite the increasing trends in consumption of skinless raw products or further-processed chicken, a significantly large volume of whole chicken and parts with skin is currently being commercialised (Sirri et al 2010). In China, Italy, Mexico, among other countries, consumer preference for yellow chicken is the main commercial driver since this trait is associated with adequate bird health and product freshness (Fletcher 1999, Breithaupt 2007, Liu et al 2008). Carotenoids are widely distributed in nature. They are synthesized by microorganisms and plants, and deposited in animal tissues throughout the food chain. Lutein, a type of

Accepted: 25.05.2017.

aDepartamento de Medicina y Zootecnia de Aves, Facultad de Medicina Veterinaria y Zootecnia, Universidad Nacional Autónoma de México, México D.F

${ }^{\mathrm{b} C}$ Centro de Enseñanza, Investigación y Extensión en Producción Avícola, Facultad de Medicina Veterinaria y Zootecnia, Universidad Nacional Autónoma de México, México D.F.

'Vepinsa S.A. de C.V. Los Mochis, Sinaloa, México.

${ }^{\mathrm{d} D e p a r t m e n t ~ o f ~ P o u l t r y ~ S c i e n c e, ~ U n i v e r s i t y ~ o f ~ A r k a n s a s, ~ F a y e t t e v i l l e, ~ U S A . ~}$ *Corresponding author: B Fuente-Martínez; benjaminfuente@yahoo. com.mx carotenoid, is a xanthophyll found in large concentrations in the petals of the Aztec marigold flower (Tagetes erecta). Since lutein has the ability to accumulate in the chicken skin and fat, it is widely used as a natural yellow pigment in the broiler industry (Hadden et al 1999, Kotake-Nara and Nagao 2011). The degree of cutaneous pigmentation in the chicken is variable. In certain regions, even within the same country, the dietary xanthophylls concentration can be so high that it may represent $10 \%$ of the feed cost (Muñoz-Díaz et al 2012).

In Mexico, the inclusion of $80 \mathrm{mg} / \mathrm{kg}$ of xanthophylls in broiler diets during the last 4 weeks prior to slaughter is commonly used to achieve an intense yellow coloration in the skin and shanks (Cuca et al 1996). Since skin pigmentation is a time and dosage-depending process, skin yellowness is expected to increase along with the time of consumption (Bilgili and Hess 2010).

Previous research studies have indicated that female chickens can achieve more intense skin pigmentation in comparison with male chickens. This phenomenon might be associated with hormonal influences and fat deposition in the females (Muñoz-Díaz et al 2012, Tyczkowski and Hamilton 1986, Martínez et al 2004, Le Bihan-Duval et al 1998, Rance et al 2002). Therefore, the objective of 
the current study is to determine the saturation point of absorption and cutaneous deposition of yellow xanthophylls (XA) in males and females broilers.

\section{MATERIAL AND METHODS}

Two hundred and sixteen 1-d-old Ross 308 broiler chickens (108 males and 108 females) were obtained from a commercial hatchery and housed in Petersime ${ }^{\circledR}$ battery brooders within an open-sided house during the whole experiment. The starter diet ( 1 to $21 \mathrm{~d}$ of age) was based on sorghum-soybean meal, and amino acids and protein were added to meet the primary breeder recommendations for the bird strain (table 1) (Aviagen 2009). At $21 \mathrm{~d}$ of age, the birds were randomly assigned to 6 dietary treatments with 6 replications (3 replications for

Table 1. Composition of the starter diet for broiler chickens from 0 to $21 \mathrm{~d}$ of age.

\begin{tabular}{|c|c|}
\hline Item & $\mathrm{kg}$ \\
\hline \multicolumn{2}{|l|}{ Ingredient } \\
\hline Sorghum & 577.72 \\
\hline Soybean meal & 340.70 \\
\hline Vegetable oil & 36.35 \\
\hline Calcium phosphate & 18.69 \\
\hline Calcium carbonate & 15.40 \\
\hline Salt & 3.82 \\
\hline DL- Methionine & 2.26 \\
\hline L-lysine hydrochloride & 2.16 \\
\hline Choline chloride $(60 \%)$ & 1.00 \\
\hline Vitamin premix $^{1}$ & 1.00 \\
\hline Mineral premix ${ }^{2}$ & 0.50 \\
\hline Zinc bacitracin & 0.30 \\
\hline Antioxidant $^{3}$ & 0.10 \\
\hline Total & 1,000 \\
\hline \multicolumn{2}{|l|}{ Calculated analysis } \\
\hline $\mathrm{ME}, \mathrm{kcal} / \mathrm{kg}$ & 3,050 \\
\hline $\mathrm{CP}, \%$ & 22.00 \\
\hline Methionine +cysteine, $\%$ & 0.90 \\
\hline Methionine, $\%$ & 0.55 \\
\hline Lysine, \% & 1.28 \\
\hline Tryptophan,\% & 0.27 \\
\hline Threonine, $\%$ & 0.82 \\
\hline Total calcium, \% & 1.00 \\
\hline Available phosphorus, $\%$ & 0.50 \\
\hline Sodium, $\%$ & 0.16 \\
\hline
\end{tabular}

${ }^{1}$ Vitamin premix supplied the following per kg: vitamin A, 20,000,000 IU; vitamin $\mathrm{D}_{3}, 6,000,000 \mathrm{IU}$; vitamin $\mathrm{E}, 75,000 \mathrm{IU}$; vitamin $\mathrm{K}_{3}, 9 \mathrm{~g}$; thiamine $3 \mathrm{~g}$; riboflavin, $8 \mathrm{~g}$; pantothenic acid, $18 \mathrm{~g}$; niacin, $60 \mathrm{~g}$; pyridoxine, $5 \mathrm{~g}$; folic acid, $2 \mathrm{~g}$; biotin, $0.2 \mathrm{~g}$; cyanocobalamin $16 \mathrm{mg}$; ascorbic acid $200 \mathrm{~g}$; ${ }^{2}$ Mineral premix supplied the following per kg: manganese, $120 \mathrm{~g}$; zinc, $100 \mathrm{~g}$; iron, $120 \mathrm{~g}$; copper, $12 \mathrm{~g}$; iodine, $0.7 \mathrm{~g}$; selenium, $0.4 \mathrm{~g}$; cobalt, $0.2 \mathrm{~g}$

${ }^{3}$ Butylated hydroxytoluene and buthoxyquin. each sex) of 6 birds each, and consisted of six levels of dietary xanthophylls from Aztec marigold flower (Florafil 93, 30g/kg, VEPINSA, Los Mochis, Sinaloa, Mexico): $65,92,119,146,173$, and 200 ppm (Muñoz-Díaz et al 2012, Frade-Negrete et al 2016). From day 21 to 49 the diets were based on sorghum-soybean meal, and were formulated to meet the nutrient recommendations of the primary breeding company (table 2) (Aviagen 2009). The feed was provided ad libitum in a mash form.

This experiment was conducted in accordance with the Guidelines for the Care and Use of Agricultural Animal in Research and Teaching, $3^{\text {rd }}$ ed., 2010 and the Guidelines of the Institutional Animal Care and Use Committee of the Facultad de Medicina Veterinaria y Zootecnia, Universidad Nacional Autónoma de México.

\section{MEASUREMENTS}

Growth performance. Body weight gain, feed consumption, and feed conversion adjusted for mortality were recorded on a weekly basis.

Skin yellowness. Throughout the experiment and twice a week between $21 \mathrm{~d}$ and $49 \mathrm{~d}$ of age, skin yellowness was measured in vivo in all birds on the right apterial latero-pectorial area, throughout the experiment, $\mathrm{L}^{*}, \mathrm{a}^{*}$, and $\mathrm{b}^{*}$ values were determined as an average of 3 measurements using a CR400 ${ }^{\circledR}$ Minolta chromameter (Chroma Meter, Model CR-400, Minolta Corp., Ramsay, NJ).

Plasma pigment. On the same d that skin yellowness was measured, a 2-ml blood sample was collected from 3 birds per pen via radial vein puncture, and mixed with EDTA at $2 \%$ as an anticoagulant. The blood samples were stored in the dark and refrigerated until further processing. Plasma xanthophylls were determined according to the method reported by Allen (1987).

\section{STATISTICAL ANALYSIS}

Before performing data analysis, the normality of data distribution was assessed with the Shapiro-Wilk test and the homocedasticity of the variances with the Levene test. The independence of the data was also reviewed. Growth performance and concentration of plasma xanthophylls data were analysed through ANOVA for a 6 X 2 factorial arrangement, where the first factor was the xanthophylls added at six levels, and the second factor was sex at two levels. When the level of xanthophylls was found to have a significant effect $(P<0.05)$, treatment means were separated using Tukey's multiple comparison procedure. Data for skin yellowness and concentration of plasma xanthophylls according to the consumption time were fitted into a multiple regression model in which the independent variables were the dietary xanthophylls level (X1), the days of consumption (X2) and the bird's sex (X3), the latter being 
Table 2. Composition of the diets for broiler chickens from 21 to $49 \mathrm{~d}$ of age $(\mathrm{kg})$.

\begin{tabular}{|c|c|c|c|c|c|c|}
\hline \multirow{2}{*}{ Item } & \multicolumn{6}{|c|}{ Dietary xanthophylls (ppm) } \\
\hline & 65 & 92 & 119 & 146 & 173 & 200 \\
\hline \multicolumn{7}{|l|}{ Ingredient } \\
\hline Sorghum & 626.83 & 625.93 & 625.03 & 624.13 & 623.23 & 622.33 \\
\hline Soybean meal & 274.79 & 274.79 & 274.79 & 274.79 & 274.79 & 274.79 \\
\hline Vegetable oil & 56.27 & 56.27 & 56.27 & 56.27 & 56.27 & 56.27 \\
\hline Calcium phosphate & 15.19 & 15.19 & 15.19 & 15.19 & 15.19 & 15.19 \\
\hline Calcium carbonate & 13.39 & 13.39 & 13.39 & 13.39 & 13.39 & 13.39 \\
\hline Salt & 3.85 & 3.85 & 3.85 & 3.85 & 3.85 & 3.85 \\
\hline Yellow pigment ${ }^{1}$ & 2.17 & 3.07 & 3.97 & 4.87 & 5.77 & 6.67 \\
\hline DL- Methionine & 3.02 & 3.02 & 3.02 & 3.02 & 3.02 & 3.02 \\
\hline L-lysine hydrochloride & 1.57 & 1.57 & 1.57 & 1.57 & 1.57 & 1.57 \\
\hline Choline chloride $(60 \%)$ & 1.00 & 1.00 & 1.00 & 1.00 & 1.00 & 1.00 \\
\hline L-Threonine & 0.02 & 0.02 & 0.02 & 0.02 & 0.02 & 0.02 \\
\hline Vitamin premix ${ }^{2}$ & 1.00 & 1.00 & 1.00 & 1.00 & 1.00 & 1.00 \\
\hline Mineral premix ${ }^{3}$ & 0.50 & 0.50 & 0.50 & 0.50 & 0.50 & 0.50 \\
\hline Zinc bacitracin & 0.30 & 0.30 & 0.30 & 0.30 & 0.30 & 0.30 \\
\hline Antioxidant ${ }^{4}$ & 0.10 & 0.10 & 0.10 & 0.10 & 0.10 & 0.10 \\
\hline Total & 1,000 & 1,000 & 1,000 & 1,000 & 1,000 & 1,000 \\
\hline \multicolumn{7}{|l|}{ Calculated analysis } \\
\hline $\mathrm{ME}, \mathrm{kcal} / \mathrm{kg}$ & \multicolumn{6}{|c|}{3,225} \\
\hline $\mathrm{CP}, \%$ & \multicolumn{6}{|c|}{19.00} \\
\hline Methionine +cysteine, $\%$ & \multicolumn{6}{|c|}{0.83} \\
\hline Methionine, $\%$ & \multicolumn{6}{|c|}{0.584} \\
\hline Lysine, \% & \multicolumn{6}{|c|}{1.05} \\
\hline Tryptophan, $\%$ & \multicolumn{6}{|c|}{0.245} \\
\hline Threonine, $\%$ & \multicolumn{6}{|c|}{0.71} \\
\hline Total calcium, \% & \multicolumn{6}{|c|}{0.85} \\
\hline Available phosphorus, $\%$ & \multicolumn{6}{|c|}{0.42} \\
\hline Sodium, $\%$ & \multicolumn{6}{|c|}{0.16} \\
\hline
\end{tabular}

${ }^{1}$ Florafil 93 powder (VEPINSA): Concentration of $30 \mathrm{~g} / \mathrm{kg}$ of Xanthophyll from aztec marigold flower (Tagetes erecta), stabilized with antioxidant and incorporated into a mixture of inert carriers.

${ }^{2}$ Vitamin premix supplied the following per $\mathrm{kg}$ : vitamin A, 20,000,000 IU; vitamin $\mathrm{D}_{3}, 6,000,000 \mathrm{IU}$; vitamin E, 75,000 IU; vitamin $\mathrm{K}_{3}, 9 \mathrm{~g}$; thiamine 3 $\mathrm{g}$; riboflavin, $8 \mathrm{~g}$; pantothenic acid, $18 \mathrm{~g}$; niacin, $60 \mathrm{~g}$; pyridoxine, $5 \mathrm{~g}$; folic acid, $2 \mathrm{~g}$; biotin, $0.2 \mathrm{~g}$; cyanocobalamin $16 \mathrm{mg}$; ascorbic acid $200 \mathrm{~g}$;

${ }^{3}$ Mineral premix supplied the following per kg: manganese, $120 \mathrm{~g}$; zinc, $100 \mathrm{~g}$; iron, $120 \mathrm{~g}$; copper, $12 \mathrm{~g}$; iodine, $0.7 \mathrm{~g}$; selenium, $0.4 \mathrm{~g}$; cobalt, $0.2 \mathrm{~g}$

${ }^{4}$ Butylated hydroxytoluene and buthoxyquin.

used as andicative variable $(0=$ females; $1=$ males $)$. To determine the inclusion of the independent variables in the model, a significance value of $P<0.05$ was used (Kuehl 2001, Neter et al 1996). In addition, a broken-line model (Robbins et al 1979) was used to find the time (day) in which the maximum levels of skin yellowing and plasma xanthophylls (saturation point) were reached.

\section{RESULTS}

Growth performance results are presented in table 3 . Weight gain, feed consumption and feed conversion were not significantly affected by the xanthophylls level $(P>0.05)$. As expected, males had significantly greater weight gain
$(P<0.05)$ compared to the females $(2,336 \mathrm{~g}$ vs $1,975 \mathrm{~g}$, respectively). Feed consumption was significantly greater in males $(4,523 \mathrm{~g})$ than in females $(4115 \mathrm{~g})(P<0.05)$. Feed conversion was significantly better in males than in females $(1.943 \mathrm{~kg}: \mathrm{kg}$ vs $2.092 \mathrm{~kg}: \mathrm{kg})(P<0.05)$.

Total pigment consumption is presented in table 3 . The higher pigment consumption was observed in birds fed the highest concentration of dietary xanthophylls $(P<0.05)$.

Skin yellowness at the end of the study was significantly greater for the females than for males $\left(21.94 \mathrm{~b}^{*}\right.$ vs $\left.18.17 \mathrm{~b}^{*}\right)$. However, regardless of the bird's sex, there were no significant differences among xanthophyll levels, except for the birds fed 65 ppm of xanthophylls which had significantly the lowest skin pigmentation (table 3 ). 
Table 3. Growth performance of broiler chickens fed different levels of Aztec marigold flower xanthophylls (Tagetes erecta) from 21 to $49 \mathrm{~d}$ of age.

\begin{tabular}{|c|c|c|c|c|c|c|}
\hline $\begin{array}{l}\text { Treatment (ppm of } \\
\text { xanthophylls) }\end{array}$ & $\begin{array}{l}\text { BW gain }{ }^{1} \\
\text { g/bird }\end{array}$ & $\begin{array}{l}\text { FCR, } \\
\mathrm{kg}: \mathrm{kg}\end{array}$ & $\begin{array}{l}\text { Feed consumption, } \mathrm{g} / \\
\text { bird }\end{array}$ & $\begin{array}{l}\text { Pigment consump- } \\
\text { tion, } \mathrm{mg} / \mathrm{bird}\end{array}$ & $\mathrm{b}^{*}$ & $\begin{array}{l}\text { Plasma xantho- } \\
\text { phyll } \mu \mathrm{g} / \mathrm{mL}\end{array}$ \\
\hline 65 & $2181^{a}$ & $1.953^{\mathrm{a}}$ & $4259^{a}$ & $277^{\mathrm{f}}$ & $17.28^{\mathrm{b}}$ & $35.2^{\mathrm{b}}$ \\
\hline 92 & $2117^{\mathrm{a}}$ & $2.009^{\mathrm{a}}$ & $4215^{\mathrm{a}}$ & $388^{\mathrm{e}}$ & $20.03^{\mathrm{a}}$ & $37.7^{\mathrm{ab}}$ \\
\hline 119 & $2067^{\mathrm{a}}$ & $2.051^{\mathrm{a}}$ & $4198^{\mathrm{a}}$ & $499^{\mathrm{d}}$ & $20.77^{\mathrm{a}}$ & $39.1^{\mathrm{ab}}$ \\
\hline 146 & $2192^{\mathrm{a}}$ & $2.005^{\mathrm{a}}$ & $4396^{\mathrm{a}}$ & $641^{\mathrm{c}}$ & $21.58^{\mathrm{a}}$ & $42.9^{\mathrm{ab}}$ \\
\hline 173 & $2194^{\mathrm{a}}$ & $2.045^{\mathrm{a}}$ & $4450^{\mathrm{a}}$ & $769^{b}$ & $19.99^{\mathrm{a}}$ & $47.7^{\mathrm{a}}$ \\
\hline 200 & $2181^{\mathrm{a}}$ & $2.042^{\mathrm{a}}$ & $4397^{\mathrm{a}}$ & $879^{a}$ & $20.70^{\mathrm{a}}$ & $39.8^{\mathrm{ab}}$ \\
\hline SEM & 85 & 0.09 & 146 & 23 & 1.23 & 2.65 \\
\hline \multicolumn{7}{|l|}{ Sex } \\
\hline Females & $1975^{\mathrm{b}}$ & $2.092^{\mathrm{a}}$ & $4115^{\mathrm{b}}$ & $550^{\mathrm{b}}$ & $21.94^{\mathrm{a}}$ & $41.1^{\mathrm{a}}$ \\
\hline Males & $2336^{\mathrm{a}}$ & $1.943^{\mathrm{b}}$ & $4523^{\mathrm{a}}$ & $601^{\mathrm{a}}$ & $18.17^{\mathrm{b}}$ & $39.7^{\mathrm{a}}$ \\
\hline \multirow[t]{2}{*}{ SEM } & 32 & 0.04 & 60 & 9 & 0.61 & 1.54 \\
\hline & \multicolumn{6}{|c|}{ ANOVA P-Value } \\
\hline Treatment & NS & NS & NS & $*$ & $*$ & * \\
\hline Sex & $*$ & $*$ & $*$ & $*$ & $*$ & NS \\
\hline Treatment*sex & NS & NS & NS & NS & NS & NS \\
\hline
\end{tabular}

${ }^{\text {a-f }}$ Means with different superscripts within a column differ significantly $(P<0.05)$.

${ }^{1} \mathrm{BW}$ gain from d 21 to 49 of age.

$* P<0.05$.

Table 4. Equations to calculate the day of highest level of skin yellowing obtained in vivo and plasma xanthophylls in broiler chickens using the broken line model.

\begin{tabular}{lcc}
\hline Treatment (ppm of xanthophylls) & $\mathrm{R}^{2}$ & Equation \\
\hline 65 & 80.00 & $-0.97+1.54 * \mathrm{~d}$ XA consumption \\
92 & 86.96 & $-0.38+1.77 * \mathrm{~d}$ XA consumption \\
119 & 83.13 & $-0.27+1.96 * \mathrm{~d}$ XA consumption \\
146 & 87.90 & $-0.16+1.94 * \mathrm{~d}$ XA consumption \\
173 & 82.50 & $-0.56+2.03 * \mathrm{~d}$ XA consumption \\
200 & 86.60 & $-0.30+1.96 * \mathrm{~d}$ XA consumption \\
plasma xanthophyll $\mu \mathrm{g} / \mathrm{mL}$ & 77.0 & $1.04+4.49 * \mathrm{~d}$ XA consumption \\
\hline
\end{tabular}

Regarding plasma xanthophylls only, a statistical difference $(P<0.05)$ was found between the groups receiving $65 \mathrm{ppm}(35.2 \mu \mathrm{g} / \mathrm{mL})$ and $173 \mathrm{ppm}(47.7 \mu \mathrm{g} / \mathrm{mL})$; while the rest of the groups were similar among them $(P>0.05)$. Sex and thee interaction sex $\mathrm{X}$ doses of xanthophylls in the feed did not affect the concentration of plasma xanthophylls $(P>0.05)$.

Figure 1 shows the effect of increasing dietary xanthophylls levels on skin yellowness (b*) according to sex and consumption time. It was determined that for every 10 ppm of increase in dietary pigment level, skin yellowness was increased by $0.83 \mathrm{~b}^{*}$. For every day that pigment was consumed, skin yellowness increased by $2.24 \mathrm{~b}^{*}$. Skin yellowness in female birds was $1.35 \mathrm{~b}^{*}$ greater than in male birds. These relationships are explained by the following equation: $b^{*}=-6.72+0.083$ (dietary xanthophylls) +2.24 (d of xanthophylls consumption) -1.35 (sex) -0.000215 (dietary xanthophylls) ${ }^{2}-0.10795$ (d of xanthophylls consumption $)^{2}+0.00190(\mathrm{~d}$ of xanthophylls consumption $)^{3}, \mathrm{R}^{2}=68.4 \%,(P<0.001)$.

Figure 2 shows the results of the analysis of in vivo skin yellowing and days of consumption using the broken line model, where it is observed that the treatment that received $65 \mathrm{ppm}$ of xanthophylls in the feed presented a maximum level of skin pigmentation at 12 days of consumption. The rest of the groups reached the maximum yellowing of the skin 11 days after the beginning of consumption (table 4).

Figure 3 shows concentration of plasma xanthophylls versus time of pigment consumption. Results indicated that sex did not influence the concentration of plasma 


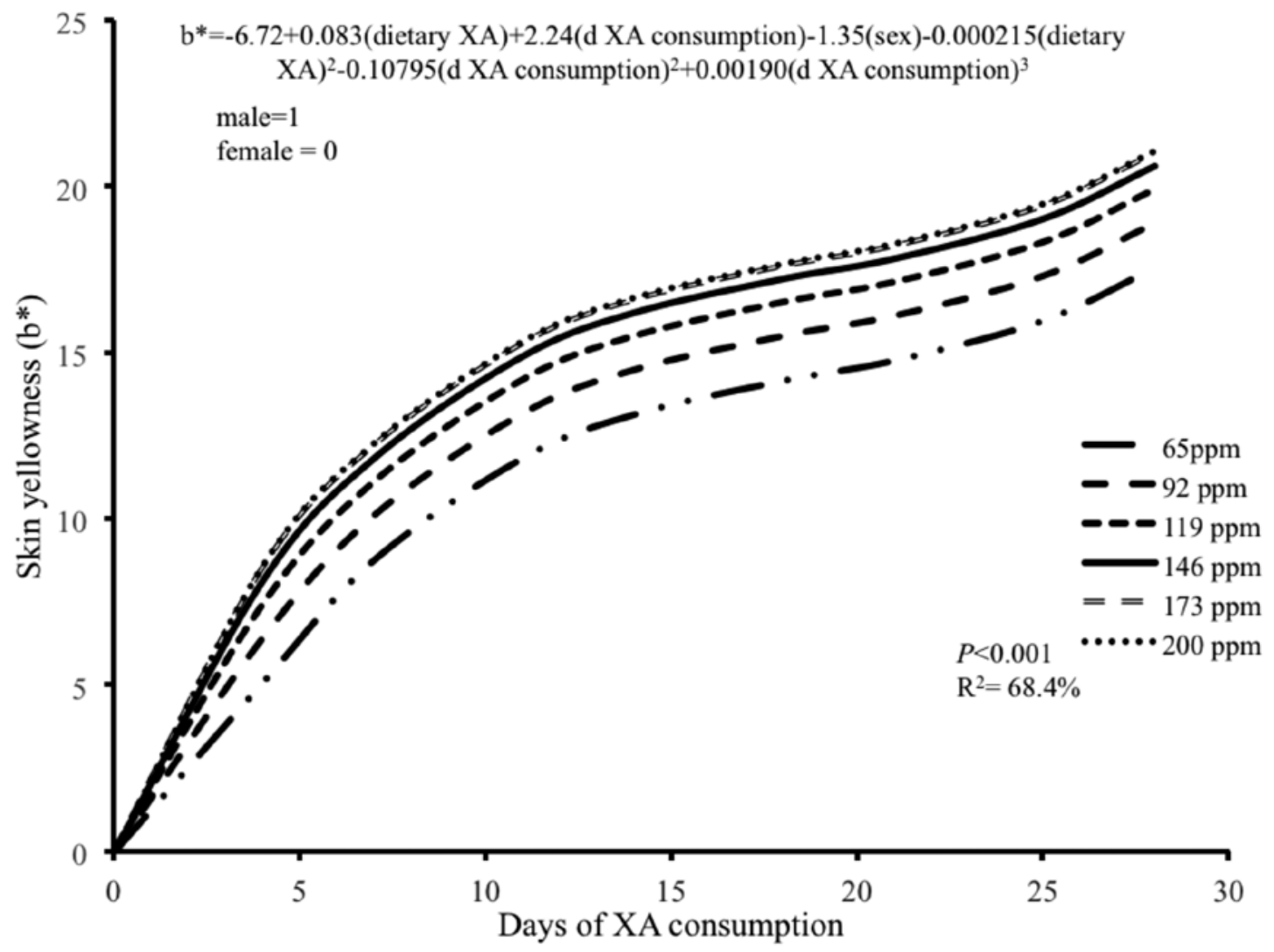

Figure 1. Skin yellowness ( $\left.b^{*}\right)$ response in broiler chickens fed increasing levels of Aztec marigold flower xanthophylls from 21 to $49 \mathrm{~d}$ of age.

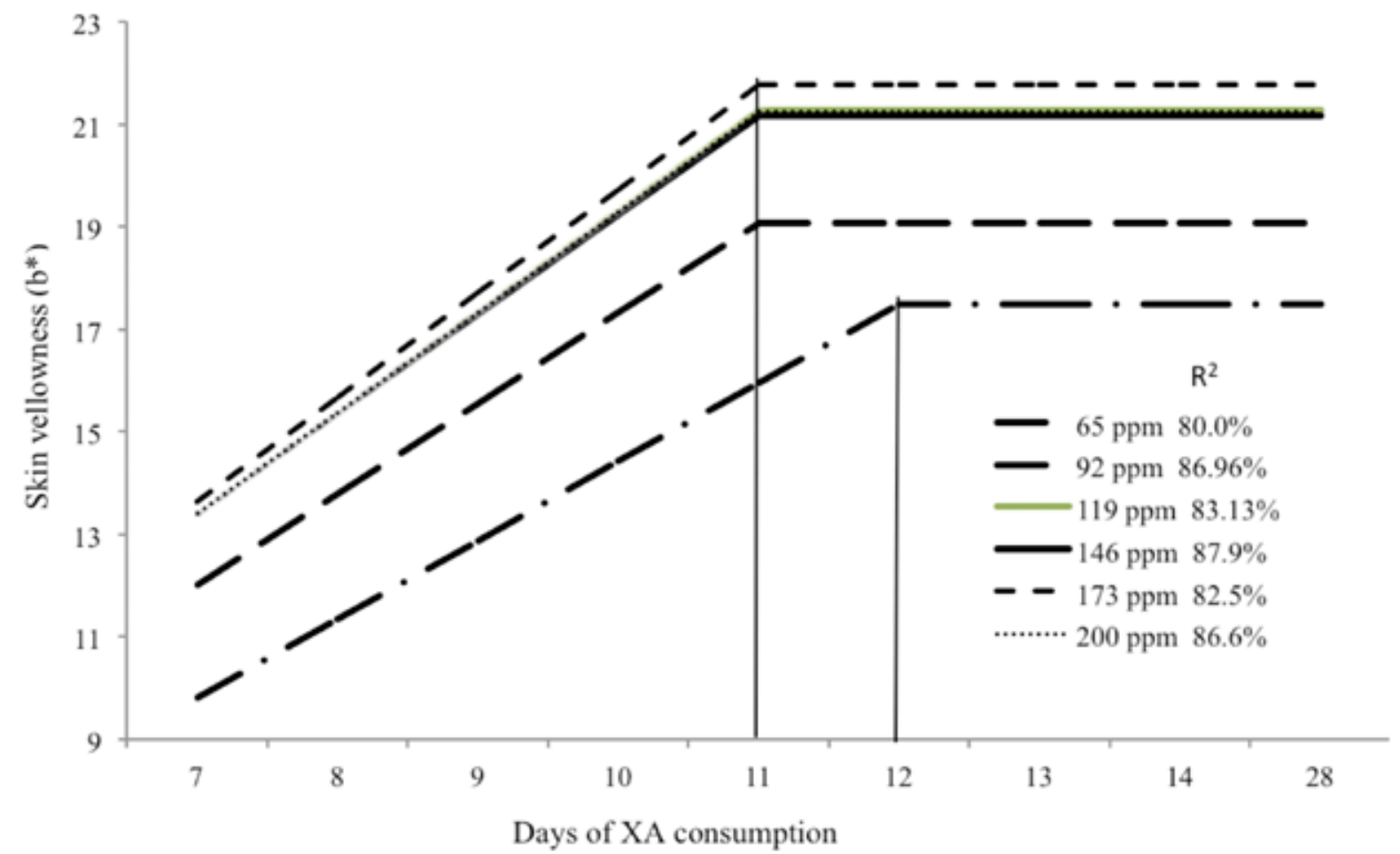

Figure 2. Time of consumption with the highest level of skin yellowing in chickens fed with different concentrations of yellow xanthophylls using the broken line model. 


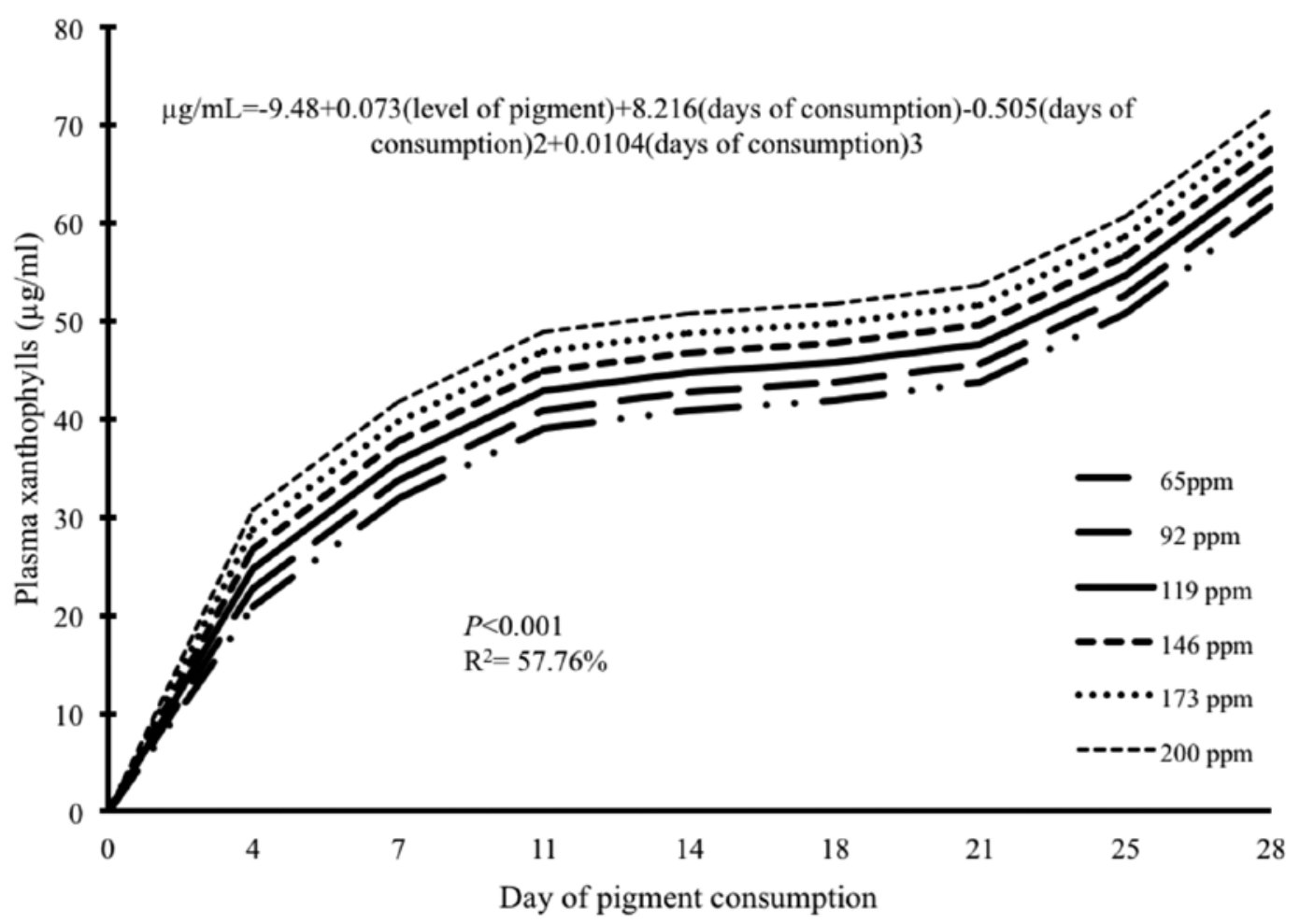

Figure 3. Concentration of plasma xanthophylls in broiler chickens fed increasing levels of Aztec marigold flower xanthophylls from 21 to $49 \mathrm{~d}$ of age. By using the Broken-line model, the first saturation point was found at 11 days, and at days 21 the plasma concentration of xanthophylls increased.

xanthophylls, for every day of pigment consumption plasma XA concentration increased by $8.216 \mu \mathrm{g} / \mathrm{mL}$. Moreover, for every ppm of xanthophylls in the feed, plasma xanthophylls increased by $0.073 \mu \mathrm{g} / \mathrm{mL}$. These relationships are explained by the following equation:

$\mu \mathrm{g} / \mathrm{mL}=-9.48+0.073$ (dietary xanthophylls) +8.21 (d of xanthophylls consumption) -0.505 (d of xanthophylls consumption $)^{2}+0.0104$ (d of xanthophylls consumption $)^{3}, \mathrm{R}^{2}=57.76 \%,(P<0.001)$ (table 4$)$.

\section{DISCUSSION}

Dietary xanthophyll level did not have any effect on growth performance, which is in agreement with previous research (Martínez et al 2004, Le Bihan-Duval et al 1998, Pérez-Vendrell et al 2001).

The birds with the lowest skin yellowness values also had the lowest pigment consumption. It is possible that the high levels of dietary pigment might keep high activity of the enzymes that re-esterify lutein for further cutaneous deposition. This would increase skin deposition of pigment in contrast with birds fed lower levels of xanthophyll. Enzyme kinetics have shown that as substrate concentration increases, the chemical reaction continues linearly until the enzyme reaches a saturation point (Nelson 2005).
In the current study, highest skin yellowness in live birds were obtained after 18 days of feeding, regardless of the dietary pigment level or the bird's sex (figure 1). By using the broken line model, it was observed that the treatment that received $65 \mathrm{ppm}$ of xanthophylls in the feed presented a maximum level of skin pigmentation at 12 days of consumption; however, it did not reach the yellowing demanded by the market for its commercialization (20 b*). The time needed to achieve maximum skin pigmentation is related to the fact that lutein needs to be transported by plasma low-density lipoproteins and undergo re-esterification by enzyme located in the tissues where lutein deposition occurs (Tyczkowski and Hamilton 1986).

Muñoz-Díaz et al (2012) reported that female birds gained $1.73 \mathrm{~b}^{*}$ more than the male broilers, when feeding $75,108,141$, and 162 ppm of dietary xanthophylls at 6 and 7 weeks of age. Sirri et al (2010) reported that females had a higher level of skin pigmentation post-slaughter in breast, thighs, and shanks $\left(24.9,22.2\right.$ y $\left.56.5 b^{*}\right)$ than males $\left(20.4,18.1,51.3 b^{*}\right)$ after receiving 12 to 15 ppm of dietary xanthophylls. The higher skin pigmentation in female birds has been explained by their higher level of subcutaneous fat, which is one of the target tissues for pigment deposition due to the xanthophyll liposoluble properties (Fletcher 1992).

Breithaupt et al (2003) found no significant differences in plasma pigment concentrations in Leghorn birds after 2 weeks of xanthophylls consumption. This response could be 
explained by the lower feed consumption observed and the lower concentration of pigment fed to the birds (10 ppm). Kostic et al (1995) reported a lutein peak in plasma at 16 hours post consumption, but found no saturation point. Park et al (1998) measured a saturation point of plasma lutein in mice after 7 days of consumption. Plasma pigment saturation may be related with the rate of absorption through the intestines, which varies between species and depends upon feed consumption. To the author's knowledge, there is no other research reported where the saturation point of plasma xanthophylls has been determined in broiler chickens. Figure 3 depicts the xanthophylls concentration in plasma as a function of time and quantity consumed $(P<0.001)$. The birds that received the highest concentration of dietary xanthophylls (200 ppm) consumed $879 \mathrm{mg}$ of xanthophylls per bird. This differs from other organs where pigments can be stored and have a higher saturation point. However, there are no studies where the time required attaining a saturation point of plasma xanthophylls or skin pigmentation had been determined. Under certain field situations, when there is a problem of poor skin pigmentation, it is not unusual to increase dietary xanthophylls concentrations to achieve the desired skin pigmentation level in a shorter period of time. However, without knowing what the saturation point of skin pigmentation is over certain time, the pigment is often wasted, which may become very costly. The results of the current study provide some basis to help optimise pigment utilisation at various times of administration and facilitates the decision-making process under practical situations. Nevertheless, further insight seems to be necessary to fully understand the physiology of pigment absorption and deposition in broiler chickens.

According to the results obtained in this study, it can be concluded that the sex did not influence the concentration of plasma xanthophylls, for every day of pigment consumption plasma xanthophylls concentration increased by 8.216 $\mu \mathrm{g} / \mathrm{mL}$. Skin yellowness increased by $0.83 \mathrm{~b}^{*}$ for every 10 ppm of dietary xanthophylls increment. For every day that dietary xanthophylls were consumed, skin yellowness increased by $2.24 \mathrm{~b}^{*}$. Skin yellowness in female broilers was greater than in males by $1.35 \mathrm{~b}^{*}$. The highest levels of plasma xanthophylls and skin yellowness were found after $11 \mathrm{ds}$ of feeding according to the broken line model.

\section{ACKNOWLEDGEMENTS}

This project was sponsored by Programa de Apoyo a Proyectos de Investigación e Innovación Tecnológica (PAPIIT) de la Dirección General de Apoyo al Personal Académico (DGAPA); Proyecto IN203910-3, Universidad Nacional Autónoma de México.

\section{REFERENCES}

Allen CP. 1987. Physiological of chicken gut tissue to coccidial infection: comparative effects of Eimeria and Eimeria acervulina and Eimeria mitis on mucosal mass, carotenoid content and brush border enzyme activity. Poult Sci 66, 1306-1315.
Aviagen. 2009. Broiler management manual Ross 308. Aviagen, Huntsville, Alabama, USA.

Bilgili SF, Hess JB. 2010. Problemas de piel en la canal de pollo: causas y soluciones. Selecciones Avícolas 52, 13-18.

Breithaupt DE, Weller P, Grashorn MA. 2003. Quantification of carotenoids in chicken plasma after feeding free or esterified lutein and capsanthin using high-performance liquid chromatography and liquid chromatography-mass spectrometry analysis. Poult Sci 82, 395-401.

Breithaupt DE. 2007. Modern application of xanthophylls in animal feeding, a review. Trends Food Sci Technol 18, 501-506.

Cuca GM, Ávila GE, Pro MA. 1996. Alimentación de las aves. $8^{\mathrm{a}} \mathrm{ed}$ Universidad Autónoma de Chapingo, Estado de México, México.

Frade-Negrete NJ, Hernández-Velasco X, Fuente-Martínez B, QuirozPesina M, Ávila-González E, et al. 2016. Effect of the infection with Eimeria acervulina, E. maxima and E. tenella on pigment absorption and skin deposition in broiler chickens. Arch Med Vet 48, 199-207.

Fletcher DL. 1992. Methodology for achieving pigment specifications. Poult Sci 71, 733-743.

Fletcher DL. 1999. Poultry meat color. In: Richardson RI, Mead GC (eds), Poultry Meat Science. CAB International, Oxon, UK, Pp 159-174.

Hadden WL, Watkins RH, Levy LW, Regalado E, Rivadeneira DM, et al. 1999. Carotenoid composition of Marigold (Tagetes erecta) flower extract used as nutritional supplement. J Agric Food Chem 47, 4189-4194.

Horneck DA, Miller RO. 1998. Determination of total nitrogen in plant tissue. In: Kalra YP (ed). Handbook of Reference Methods for Plant Analysis. $2^{\text {nd }}$ ed. CRC Press, Washington DC, USA, Pp 75-83.

Kostic D, White WS, Olson JA. 1995. Intestinal absorption, serum clearance, and interactions between lutein and beta-carotene when administered to human adults in separate or combined oral doses. Am J Clin Nutr 62, 604-610.

Kotake-Nara E, Nagao A. 2011. Absorption and metabolism of xanthophylls. Mar Drugs 9, 1024-1037.

Kuehl R. 2001. Diseño de experimentos: Principios estadísticos de diseño y análisis de investigación. $2^{\mathrm{a}}$ ed. Universidad de Arizona, Arizona, Estados Unidos, Pp 120-145.

Le Bihan-Duval E, Mignon-Grasteau S, Millet N, Beaumont C. 1998. Genetic analysis of a selection experiment on increased body weight and breast muscle weight as well as on limited abdominal fat weight. Br Poult Sci 39, 346-353.

Liu GD, Hou GY, Wang DJ, Lv SJ, Zhang XY, et al. 2008. Skin pigmentation evaluation in broilers fed different levels of natural okra and synthetic pigments. J Appl Poult Res 17, 498-504.

Martínez PM, Cortés CA, Ávila GE. 2004. Evaluación de tres niveles de pigmento de flor de cempasúchil (Tagetes erecta) sobre la pigmentación en la piel de pollos de engorda. Tec Pecu Mex 42, 105-111.

Muñoz-Díaz JI, Fuente-Martínez B, Hernández-Velasco X, Ávila-González E. 2012. Skin pigmentation in broiler chickens fed various levels of metabolizable energy and xanthophylls from Tagetes erecta. J Appl Poult Res 21, 788-796.

Nelson DL. 2005. Lehninger principles of biochemistry. $4^{\mathrm{a}}$ ed. Worth, New York, USA, Pp 343-337.

Neter J, Wasserman W. 1985. Applied linear statistical models. Richard D Irwin Inc, New York, USA, Pp 120-145.

Pérez-Vendrell AM, Hernández JM, Llaurado L, Schierle J, Brufau J. 2001. Influence of source and ratio of xanthophyll pigments on broiler chicken pigmentation and performance. Poult Sci 80, 320-326.

Rance KA, McEntee GM, McDevitt RM. 2002. Genetic and phenotypic relationships between and within support and demand tissues in a single line of broiler chicken. Br Poult Sci 43, 518-527.

Robbins KR, Norton HW, Baker DH. 1979. Estimation of nutrient and requirements from growth data. J Nutr 109, 1710-1714.

Sirri F, Petracci M, Bianchi M, Meluzzi A. 2010. Survey of skin pigmentation of yellow-skinned broiler chickens. Poult Sci 89, 1556-1561.

Tyczkowski JK, Hamilton PB. 1986. Absorption, transport, and deposition in chickens of lutein diester, a carotenoid extracted from marigold (Tagetes erecta) petals. Poult Sci 65, 1526-1531. 
